\title{
EFFECTS OF ULTRASOUND ON TRANSFORMING GROWTH FACTOR-B GENES IN BONE CELLS
}

\author{
J. Harle ${ }^{1,2}$, F. Mayia ${ }^{2}$, I. Olsen ${ }^{3}$ and V. Salih ${ }^{4, *}$ \\ ${ }^{1}$ University Department of Radiology, Oxford, UK; ${ }^{2}$ Department of Medical Physics and Clinical Engineering, \\ Oxford Radcliffe Hospitals NHS Trust, Oxford, UK; Departments of ${ }^{3}$ Periodontology and ${ }^{4}$ Biomaterials, Eastman \\ Dental Institute, University College London, London, UK
}

\begin{abstract}
Therapeutic ultrasound (US) is a widely used form of biophysical stimulation that is increasingly applied to promote fracture healing. Transforming growth factor-beta (TGF- $\beta$ ), which is encoded by three related but different genes, is known to play a major part in bone growth and repair. However, the effects of US on the expression of the TGF- $\beta$ genes and the physical acoustic mechanisms involved in initiating changes in gene expression in vitro, are not yet known. The present study demonstrates that US had a differential effect on these TGF- $\beta$ isoforms in a human osteoblast cell line, with the highest dose eliciting the most pronounced up-regulation of both TGF- $\beta 1$ and TGF- $\beta 3$ at 1 hour after treatment and thereafter declining. In contrast, US had no effect on TGF- $\beta 2$ expression. Fluid streaming rather than thermal effects or cavitation was found to be the most likely explanation for the gene responses observed in vitro.
\end{abstract}

Keywords : Ultrasound, Bone, Cells, Culture, Genes, Polymerase chain reaction, Biophysical stimuli, Mechanisms, Acoustics, Non-invasive technique

*Address for correspondence:

V. Salih

Biomaterials and Tissue Engineering,

Eastman Dental Institute,

University College London,

256 Gray's Inn Road,

London, WC1X 8LD, UK

Telephone Number: $+44-207-9151133$

Fax Number: +44-207-9151227

Email: v.salih@eastman.ucl.ac.uk

\section{Introduction}

Applying load to a bone fracture site is well known to influence its resultant repair and remodelling (Wolff, 1986; Rubin and Lanyon, 1984). Over the past two decades, a range of alternative techniques that apply a biophysical stimulus to the fracture site, such as therapeutic ultrasound (US) or pulsed electromagnetic fields, have also been shown to accelerate fracture healing (Chao and Inoue, 2003). Such new techniques offer the potential for noninvasive therapies that can accelerate the normal healing process or provide an alternative treatment in cases of abnormal healing such as nonunion or delayed union.

Therapeutic ultrasound (US) has for many years accounted for $15-20 \%$ of all rehabilitative physiotherapy treatments of soft tissue injury and localized joint pain (Warden and McMeeken, 2002). For hard tissue treatment, the USA Food and Drug Administration (FDA) has in recent years approved the use of low intensity US for treating bone fractures, based on promising clinical trials and animal studies. Several studies have demonstrated a consistent $30-40 \%$ improvement in healing time and quality at a number of fracture sites (Pilla et al., 1990; Heckman et al., 1994; Wang et al., 1994; Kristiansen et al., 1997; Ryaby et al., 1997; Azuma et al., 2001).

In addition to fracture sites, US treatment has shown promise as a tissue engineering tool at the biomaterialbone interface. Lin et al. (1995) reported that low intensity pulsed ultrasound enhanced the rate of bone regeneration and implant bioabsorption for a DP-bioglass bone substitute in the rabbit femur. Furthermore in a canine model of porous-coated implants, ultrasound-stimulated implant sites showed enhanced bone ingrowth (Tanzer et al., 1996), most notably at higher intensities (Tanzer et al., 2001).

Establishment of such cellular mechanisms and its dose effect and application timing has been noted as key requirements in furthering the usage and efficacy of techniques of biophysical stimulation (Chao and Inoue, 2003), such as US treatment for accelerated fracture repair, treatment of nonunion or improved implant biocompatibility. Despite the apparent beneficial effects on the repair of damaged hard tissue, little is known about the precise mechanisms by which US elicits favourable biological responses that result in improved healing. In vitro studies have suggested that low doses of US can influence the expression of certain connective tissue proteins and integrins in bone-derived cells (Reher et al., 1997; Harle et al., 2001 a; Yang et al., 2005), possibly by activation of growth factor and early response genes such 
as IGF-I, IGF-II and COX-2 (Warden et al., 2000). Similar intensities of US have also been reported to modulate the synthesis of the growth factor transforming growth factorbeta (TGF- $\beta$ ) by bone cells in vitro (Ryaby et al., 1992), although other studies have found little if any effect of US on TGF- $\beta$ gene expression (Warden et al., 2000; Naruse et al., 2000).

TGF- $\beta$ is a major growth factor in many types of cell and has widespread activity in many essential cellular functions, ranging from control of cell cycle progression to the regulation of extracellular matrix production (Bonewald, 1999; Croucher and Russell, 1999). It is present in humans as three different $25 \mathrm{kDa}$ isoforms encoded by three distinct genes (Croucher and Russell, 1999). These isoforms are considered to have different functional roles, as shown by isoform-specific outcomes from transgenic mouse 'knock-out' studies (Bonewald, 1999). It is thus possible that previously reported discrepancies in the effects of US on TGF- $\beta$ may be related to the presence, and differential expression, of these different TGF- $\beta$ isoforms.

The present study has additionally addressed the issue of which acoustic mechanisms may be eliciting such biological effects in vitro. The extent of the three main acoustic mechanisms attributed to the induction of biological effects, namely heating, cavitation and radiation force (Dyson, 1987), are each examined by one experiment in order to assess their likelihood and impact on biological response within the ultrasound exposure system.

Thus, the present study has measured, for the first time, the effects of a range of US intensity levels on the expression of all three TGF- $\beta$ genes. Furthermore, it has also examined the relative roles of heating, cavitation and bulk fluid streaming, the main acoustic mechanisms by which US is likely to be able to exert biological effects (Dyson, 1987).

\section{Materials and Methods}

\section{Cell culture}

The osteosarcoma MG63 cell line (obtained from the Institute of Orthopaedics, University of London) has been shown to exhibit a number of characteristics of bone cells (Clover and Gowen, 1994) and was used in the present study. The cells were grown as adherent monolayers in Dulbecco's Minimum Essential Medium (DMEM) (Gibco Life Technologies Ltd, Paisley, UK), 10\% heat-inactivated foetal calf serum (PAA Laboratories, Linz, Austria), 2 mM L-glutamine (Gibco), $100 \mathrm{U} / \mathrm{ml}$ of penicillin (Gibco) and $100 \mu \mathrm{g} / \mathrm{ml}$ of streptomycin (Gibco) at $37^{\circ} \mathrm{C}$ in a humidified atmosphere of $5 \% \mathrm{CO}_{2}$ in air. Cells were detached by addition of $0.25 \%$ trypsin-1 mM EDTA (EthyleneDiamineTetraAcetic acid, Gibco) for $5 \mathrm{~min}$ at $37^{\circ} \mathrm{C}$, washed by centrifugation and re-cultured in new flasks (Falcon, Becton Dickinson, Cowley, UK).

\section{Ultrasound exposure}

Calibration of the US source was established by means of hydrophonic field plotting within a purpose-built US plotting tank, using a $1.0 \mathrm{~mm}$ diameter submersible PVdF needle hydrophone (Precision Acoustics, Dorchester, UK), as previously described (Harle et al., 2001a). An unfocussed $22 \mathrm{~mm}$ diameter piezoelectric lead zirconate titanate (PZT) crystal, acoustically coupled to a purposebuilt exposure assembly, was used to deliver US to cells growing as a monolayer in a $16 \times 16 \mathrm{~mm}$ square central region of a $12.5 \mathrm{~cm}^{2}$ cell culture flask. A value of acoustic intensity $\left(\mathrm{I}_{\mathrm{SATA}}\right.$, the spatial average temporal average intensity) was calculated for this target area for output intensities at low $\left(130 \mathrm{~mW} / \mathrm{cm}^{2}\right)$, medium $(480 \mathrm{~mW} /$ $\left.\mathrm{cm}^{2}\right)$ and high $\left(1770 \mathrm{~mW} / \mathrm{cm}^{2}\right)$ therapeutic doses. For exposure at these calibrated US levels, the cells were seeded at a high density ( $1.5 \times 10^{5}$ cells per flask), incubated for two days and the flasks then filled with culture medium. US was applied at $3.00 \mathrm{MHz} \mathrm{CW}$ (Continuous Wave, i.e. no pulsing) for $10 \mathrm{~min}$ at each US intensity, with control cells receiving no US exposure. Following exposure, the medium was removed and the cells re-cultured with fresh medium for the time periods indicated. Cells outside the target region were removed using a cell scraper (Falcon) and the cells remaining (within the target region) collected by addition of trypsinEDTA. Following centrifugation, the cell pellet was resuspended in $5 \mathrm{ml}$ of RNAlater (Ambion, Huntingdon, UK), an RNA stabilization and preservative agent, and stored at $-20^{\circ} \mathrm{C}$.

\section{RNA isolation and RT-PCR}

Total RNA was extracted from the frozen and thawed RNAlater cell suspensions using RNeasy (Qiagen, Germantown, USA), in accordance with manufacturer's instructions. A total of $5 \mu \mathrm{g}$ of cellular RNA was used for reverse transcription (RT) with 500 ng oligo-dT (Promega, Madison, USA) in $40 \mu$ l of water containing $0.1 \%$ DiEthyl PyroCarbonate (DEPC) (Sigma). After 5 min at $65^{\circ} \mathrm{C}$, the first strand of cDNA was synthesized in a total volume of $50 \mu \mathrm{l}$, containing $50 \mathrm{U}$ of M-MuLV reverse transcriptase, 1x M-MuLV buffer, $10 \mathrm{pmol}$ of each dNTP, and $40 \mathrm{U}$ of RNAse block (all Stratagene, La Jolla, USA). After incubation at $37^{\circ} \mathrm{C}$ for $60 \mathrm{~min}$, the enzyme was inactivated by incubation for $5 \mathrm{~min}$ at $90^{\circ} \mathrm{C}$. Subsequently, $5 \mu \mathrm{l}$ of each cDNA sample was added to a $50 \mu 1$ polymerase chain reaction (PCR) reaction mix containing 1.5 U REDTaq DNA polymerase, 1x REDTaq PCR buffer, 10 pmol of each dNTP (all Sigma), and 12.5 pmol of the respective sense and antisense primer pair sequences (SigmaGenosys, Pampisford, UK) for TGF- $\beta 1$, TGF- $\beta 2$, TGF$\beta 3$, as previously published (El-Sherif et al., 2000). Replicate reaction tubes containing the primer pairs for the housekeeping gene GAPDH (GlycerAldehyde-3Phosphate DeHydrogenase) were also used for each cDNA sample as an internal control, as previously described (Das and Olsen, 2001). PCR was carried out using a PCT-100 thermal cycler (MJ Research, Boston, USA) with an initial $3 \mathrm{~min} 94^{\circ} \mathrm{C}$ denaturation step, followed by cycles of denaturation, annealing and extension of $30 \mathrm{~s}$ at $94^{\circ} \mathrm{C}, 120$ $\mathrm{s}$ at $61^{\circ} \mathrm{C}$ and $120 \mathrm{~s}$ at $72^{\circ} \mathrm{C}$, respectively, with a terminal $10 \min 72^{\circ} \mathrm{C}$ step. 34 cycles were used for TGF- $\beta 1,36$ cycles for TGF- $\beta 2$ and TGF- $\beta 3$ and 32 cycles for GAPDH, which were found to be within the linear range of PCR amplification (data not shown). The amplified products 
were separated using agarose gel electrophoresis and visualized by ethidium bromide staining with ultraviolet illumination image capture (MultiImage Light Cabinet, Alpha Innotech, San Leandro, USA). After electrophoresis, image analysis of the gels was carried out using Scion Image software (Scion Corporation, Frederick, USA) to record band intensities of the target TGF- $\beta$ genes and the control GAPDH gene. From the area of the resultant histograms, the ratio of TGF- $\beta$ isoform expression to GAPDH expression was determined at each dose, and compared with the control which was not exposed to US. Studies were initially performed once at each time point and intensity level, and then repeated three times when an US-induced change in TGF- $\beta$ gene expression relative to control was evident.

\section{Heating measurements}

A medical infrared thermometer (IRT3520, Braun $\mathrm{GmbH}$, Kronberg, Germany) was waterproofed and used to measure the temperature of the inner polystyrene surface of a culture flask during exposure at each intensity level. The thermometer records eight readings per measurement, and displays the highest value, allowing for the assessment of any localized 'hot spot' heating areas produced by the US field. Recordings at the plastic surface were made at $1 \mathrm{~min}$ intervals during exposure and repeated 5 times, with average values reported \pm standard error $(\mathrm{SE})$.

\section{Cavitation measurement}

The possible role of acoustic cavitation within the culture flask was assessed by spectral analysis of the acoustic signals from the target region, using a modification of the procedure of Morton et al. (1982). This was determined by measuring the first sub-harmonic content of the acoustic signals emitted from the region of target cells ( $f_{0} / 2$ content) compared with the transducer frequency $\left(\mathrm{f}_{\mathrm{o}}\right)$. This $\mathrm{f}_{\mathrm{o}} / 2$ component, resulting from non-linear driving of unstable and rapidly growing bubbles, is used as a marker of acoustic cavitation (Neppiras, 1968). To obtain these measurements, a $1.0 \mathrm{~mm}$ hydrophone was inserted at $90^{\circ}$ to the direction of US propagation within the culture flask and the hydrophone output captured using a digital oscilloscope (Tektronix, Marlow, UK). The data was analysed using Excel 98 'Data Analysis Toolpack' software (Microsoft, Redmond, USA) and normalized relative to the $f_{0}$ component of the signal. At least 4 spectral analyses were performed per intensity level.

\section{Acoustic streaming measurement}

Acoustic streaming at the position of the target cells within the US exposure system was assessed using a modification of a technique previously reported by Zauhar et al. (1998). A 4.00 MHz CW Doppler US system (Flowscan, Appleton Ultrasound, Southampton, UK) was used to measure flow velocities of $1 \mathrm{~mm}^{3}$ Perspex chips added to the exposure environment under different exposure intensities, with holes cut in the culture flasks to permit free flow of water by radiation forces along the beam axis. Results of the Doppler shift values were compared with a flow velocity-Doppler shift calibration curve, performed at identical geometry, using a Doppler US string phantom (Phantom Mk 4, JJ\&A Instruments, Duvall, USA) to equate recorded results to streaming velocities. Results were repeated at least 8 times per exposure level, and reported as average velocity \pm SE.

\section{Statistical analysis}

Statistical analysis used SPSS 11.0 software (SPSS, Chicago, USA), with a two-tailed one-sample Students' $t$-test assessing significance relative to control values which were defined as $100 \%$, with $p<0.05$ considered significant.

\section{Results}

\section{Gene expression}

Representative electrophoresis gels of the effects of US on each of the TGF- $\beta$ genes at $1 \mathrm{~h}$ are shown in Fig. 1. While the intensity of the GAPDH band was observed to be approximately the same at each intensity level, there was notable variation in the expression of the different TGF- $\beta$ genes at each of the US intensities. Thus, in this particular experiment, there appeared to be a dosedependant up-regulation of TGF- $\beta 1$ at $1 \mathrm{~h}$, whereas TGF$\beta 2$ expression was very similar to the control level at all US intensities. In contrast, at this early time period upregulation of the TGF- $\beta 3$ gene was observed at all US doses relative to control expression (Fig.1). Although some small differences were also observed at $3 \mathrm{~h}$ after US exposure, at 6 and $12 \mathrm{~h}$ the relative levels of expression of each of the TGF- $\beta$ isoforms was very
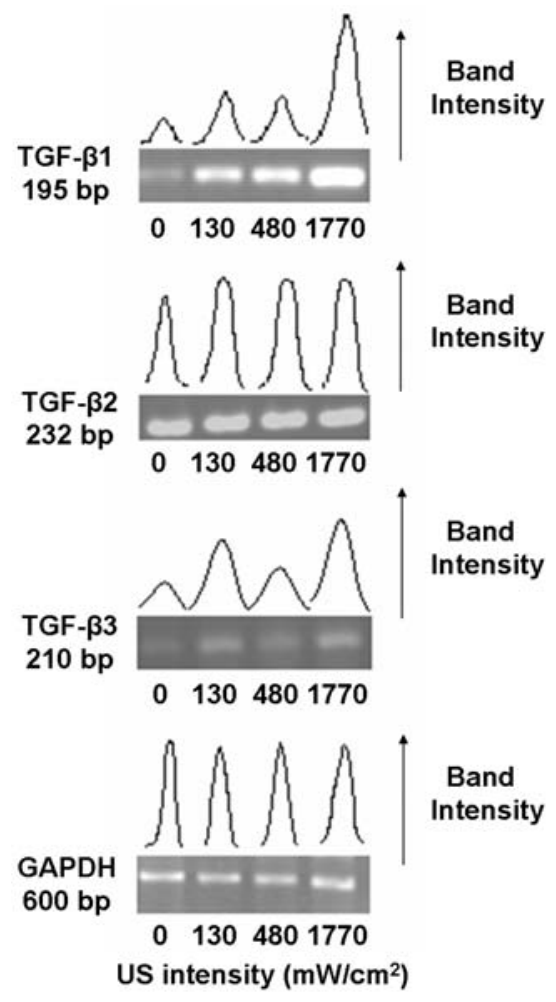

Figure 1. Representative agarose electrophoresis gels of the RT-PCR products of the TGF- $\beta$ genes in MG63 cells exposed to different intensities of US $(0,130$, $480,1770 \mathrm{~mW} / \mathrm{cm}^{2}$ ). Image analysis of the resulting band intensities is also shown, including that of the housekeeping gene, GAPDH, in each cDNA sample. 


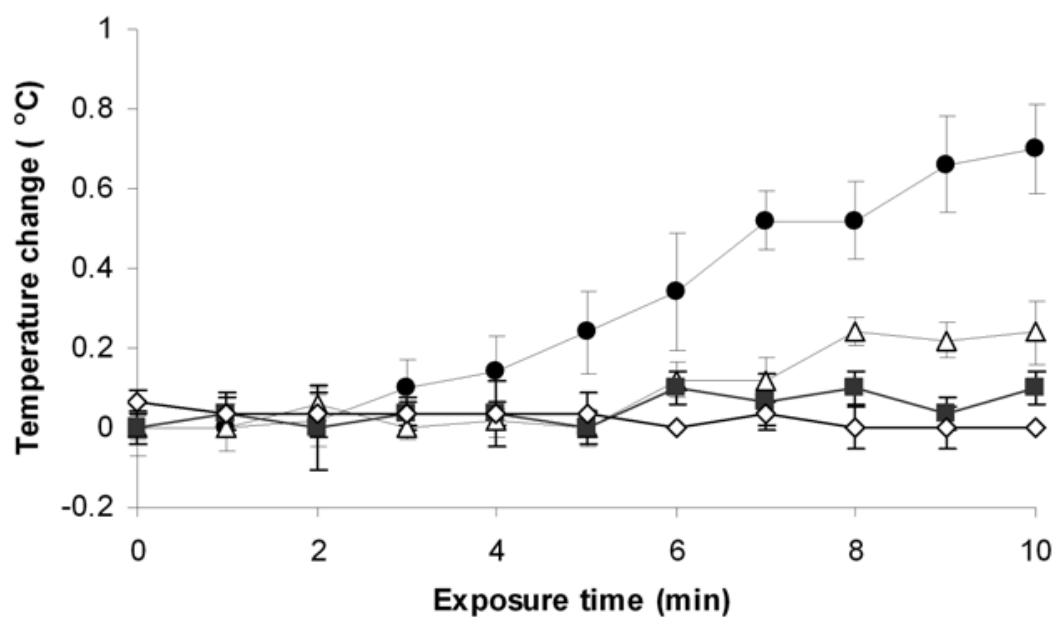

Figure 2. US-induced temperature changes at the monolayer surface of the culture flask. $\mathrm{I}_{\text {SATA }}$ levels were $(\prec-)$ $0 \mathrm{~mW} / \mathrm{cm}^{2}$ control, (- $(-) 130 \mathrm{~mW} / \mathrm{cm}^{2},(-\smile) 480 \mathrm{~mW} / \mathrm{cm}^{2}$, (-) $1770 \mathrm{~mW} / \mathrm{cm}^{2}$. The ambient water bath temperature was $37.4^{\circ} \mathrm{C}$. Results are presented as mean $\pm \mathrm{SE}$.

similar to those of the control cultures which received no US treatment (data not shown). The results of replicate RT-PCR experiments in Table 1 shows that at $1 \mathrm{~h}$ the two lowest US doses increased the mean TGF- $\beta 1$ expression more than 2-fold, while expression at the highest dose of US resulted in a statistically significant increase of more than $500 \%$ relative to the control level $(p<0.05)$. At $3 \mathrm{~h}$, however, there was no significant up-regulation of this isoform by any of the US intensities tested. TGF- $\beta 2$ gene expression showed little change relative to the control nonexposed cultures at both 1 and $3 \mathrm{~h}$, whereas TGF- $\beta 3$ was significantly up-regulated to more than $200 \%$ at all intensities $(p<0.05)$. Although this isoform was still upregulated to approximately $150 \%$ at $3 \mathrm{~h}$, these differences were not significantly different from control cultures.

\section{Acoustic mechanisms}

Changes in the temperature of the monolayer plastic were measured to determine the possible role of the thermal effects of US in causing the gene changes observed. The results in Fig. 2 show that the temperature gradually increased during the 10 min of US exposure to all intensity levels. However, only very small temperature changes, less than $\pm 0.1^{\circ} \mathrm{C}$, were recorded throughout this period in the control and lowest US exposure, and an increase of only $0.2^{\circ} \mathrm{C}$ was measured after $8 \mathrm{~min}$ at $480 \mathrm{~mW} / \mathrm{cm}^{2}$. In contrast, at the highest intensity $\left(1770 \mathrm{~mW} / \mathrm{cm}^{2}\right)$ the temperature progressively increased after $3 \mathrm{~min}$ and by 10 min was $0.7^{\circ} \mathrm{C}$ higher than the exposure tank temperature. Fig. 3 shows the assessment of cavitational activity as identified by presence of a first subharmonic component $\left(f_{0} / 2\right)$ from acoustic signal emitted and scattered by the culture medium exposed at fundamental frequency $f$. An $\mathrm{f}_{\mathrm{o}} / 2$ component was detected only at the highest intensity level with no such sub-harmonic component apparent at 130 and $480 \mathrm{~mW} / \mathrm{cm}^{2}$ or in control cultures, in 4 separate experiments. The presence of a $2 \mathrm{f}$ component at all intensity levels was also noted and is attributed to the effects of non-linear propagation, a property of sound waves not associated with cavitation (Duck, 2002). In order to measure the velocity of US fluid streaming a calibration of streaming velocities was first established, using a string phantom. This produced a linear calibration curve with the equation [Doppler frequency $(\mathrm{Hz})=282 \mathrm{x}$ velocity $(\mathrm{cm} / \mathrm{s})$ ] (data not shown). The results of Doppler shift analysis, as described in Materials and Methods, shows that increasing intensities of US caused a progressive increase in steaming velocity values, which

\begin{tabular}{|c|c|c|c|c|}
\hline \multirow{2}{*}{ TGF- $\beta$ gene } & \multirow{2}{*}{$\begin{array}{c}\text { Time after } \\
\text { exposure }(\mathrm{h})\end{array}$} & \multicolumn{3}{|c|}{ Relative gene expression (\% of control) } \\
\cline { 3 - 5 } & & $130 \mathrm{~mW} / \mathrm{cm}^{2}$ & $480 \mathrm{~mW} / \mathrm{cm}^{2}$ & $1770 \mathrm{~mW} / \mathrm{cm}^{2}$ \\
\hline \multirow{2}{*}{ TGF- $\beta 1$} & 1 & $214 \pm 98$ & $240 \pm 125$ & $522 \pm 232 *$ \\
\cline { 2 - 5 } & 3 & 92 & 149 & 106 \\
\hline \multirow{2}{*}{ TGF- $\beta 2$} & 1 & $128 \pm 36$ & $124 \pm 41$ & $115 \pm 47$ \\
\cline { 2 - 5 } & 3 & 204 & 147 & 88 \\
\hline \multirow{2}{*}{ TGF- $\beta 3$} & 1 & $255 \pm 87 *$ & $201 \pm 25^{*}$ & $332 \pm 102 *$ \\
\cline { 2 - 5 } & 3 & 143 & 168 & 143 \\
\hline
\end{tabular}

Table 1 Effects of US on the expression of TGF- $\beta$ genes. Gene expression of TGF- $\beta 1$, TGF- $\beta 2$ and TGF- $\beta 3$ in MG63 cells at three different intensity levels of US at 1 and $3 \mathrm{~h}$ post-exposure. The expression of each TGF- $\beta$ gene was calculated compared with that of the housekeeping gene GAPDH, an internal control, defined as 1.0. These ratios have been compared with the TGF- $\beta$ :GAPDH ratio obtained in non-exposed control cultures, defined as $100 \%$. At $1 \mathrm{~h}$, the values are expressed as mean \pm SE. * denotes $p<0.05$ vs. control. 


\begin{tabular}{|c|c|c|}
\hline $\begin{array}{c}\text { US intensity } \\
\left(\mathrm{mW} / \mathrm{cm}^{2}\right)\end{array}$ & $\begin{array}{c}\text { Doppler shift } \\
(\mathrm{Hz}) \pm \mathrm{SE}\end{array}$ & $\begin{array}{c}\text { Streaming velocity } \\
(\mathrm{cm} / \mathrm{s})\end{array}$ \\
\hline 0 & 0 & 0 \\
\hline 130 & $120 \pm 80$ & 0.4 \\
\hline 480 & $1700 \pm 120$ & 6.0 \\
\hline 1770 & $5420 \pm 180$ & 19.4 \\
\hline
\end{tabular}

Table 2 Effects of US intensity on fluid streaming velocity. Velocities were measured as Doppler shift values $( \pm \mathrm{SE})$ from a $4.00 \mathrm{MHz}$ peripheral US diagnostic unit, measured using small perspex chips traveling within the fluid flow in the exposure assembly, at each US intensity. Doppler shift were related to velocities by string phantom calibration, as outlined in Materials and Methods.

were $0.4,6.0$ and $19.4 \mathrm{~cm} / \mathrm{s}$ at 130, 480 and $1770 \mathrm{~mW} /$ $\mathrm{cm}^{2}$, respectively (Table 2 ).

\section{Discussion}

TGF- $\beta$ is the most abundant growth factor in bone, with functionally important roles in bone formation and repair as evidenced by its ability to induce new bone formation following in vivo injection (Noda and Camilliere, 1989) and its up-regulation at both the gene (Cho et al., 2002) and protein (Steinbrech et al., 2000) level during fracture repair. The presence of three different human isoforms of the growth factor have been well-documented and have been shown to be expressed differentially during fracture repair (Rosier et al., 1998; Cho et al., 2002). Because the healing of bone fractures has also been widely reported to be enhanced by US in vivo, the present study has examined the effects of therapeutic levels of US on the expression of the TGF- $\beta$ genes in bone-derived cells in vitro.

Using a semi-quantitative RT-PCR technique, it was found that US up-regulated the TGF- $\beta 1$ and TGF- $\beta 3$, but not the TGF- $\beta 2$, gene in the bone-like MG63 cell line. However the increased expression of these two TGF- $\beta$ genes was found to be most marked at $1 \mathrm{~h}$ after US exposure, after which gene expression levels declined. While in vitro studies on TGF- $\beta 2$ and TGF- $\beta 3$ expression are poorly documented, the rapid up-regulation of TGF$\beta 1 \mathrm{mRNA}$ has previously been shown to occur in bonelike cells as a result of fluid flow-induced shear stress (Sakai et al., 1998) and also during mechanical stretching of osteoblasts (Zhuang et al., 1996).

The extent of up-regulation was also found to be dependent on the dose of US, with the low and medium intensities eliciting an increase of approximately 2-fold and the highest dose inducing an increase of 500 and $300 \%$ in TGF- $\beta 1$ and TGF- $\beta 3$, respectively. These intensity levels encompass those used in the most widespread application of US in hospital physiotherapy treatment protocols (Warden and McMeeken, 2002). However, the lower levels of US $\left(30 \mathrm{~mW} / \mathrm{cm}^{2}\right.$ at $\left.1.5 \mathrm{MHz}\right)$ delivered by the first FDA-approved US fracture healing device (SAFHS, Exogen, NJ), while up-regulating the expression of a number of other growth factors and bone-associated genes, has been reported to have no effect on TGF- $\beta 1$ gene
US intensity
$\left(\mathrm{mW} / \mathrm{cm}^{2}\right)$
Spectral analysis
(a)
$0 \mathrm{~mW} / \mathrm{cm}^{2}$

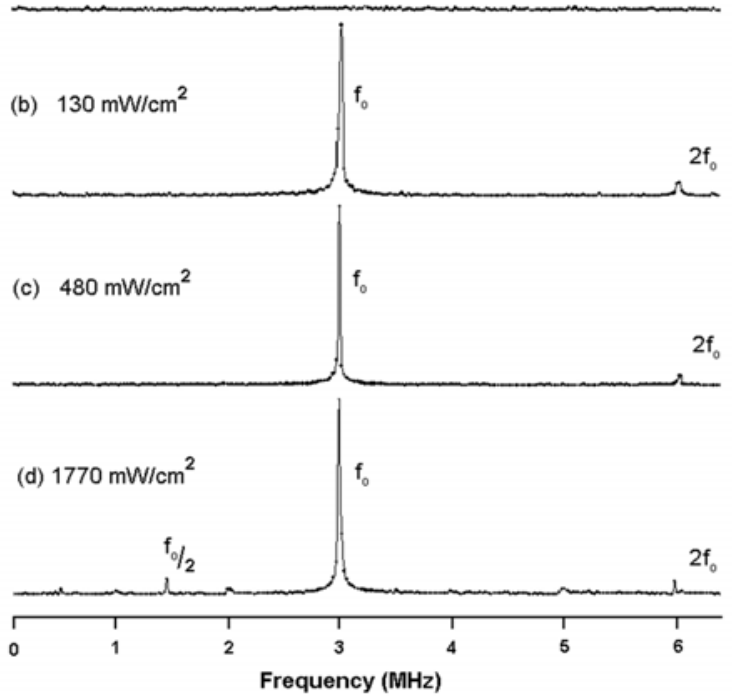

Figure 3. Representative analysis of the spectral content of US beam scatter measured within the exposure assembly during US application at each intensity level. The presence of the first sub-harmonic $\left(\mathrm{f}_{\mathrm{o}} / 2\right)$ frequency component indicates acoustic emission as a result of cavitational activity, with the $f_{o}$ and $2 f_{o}$ components resulting from scatter of the fundamental and first harmonic signal components, respectively.

expression in vitro (Warden et al., 2000; Naruse et al., 2000). It is thus possible that the higher intensity levels used in the present study may be required, at least at 3.00 $\mathrm{MHz}$, to elicit a measurable effect of US on TGF- $\beta$, as we have previously shown for bone-associated genes such as osteopontin (OP) and alkaline phosphatase (ALP) (Harle et al., 2001b). Moreover, since TGF- $\beta$ genes have been shown differentially to regulate the expression of the OP and ALP genes in bone cells (Fagenholz et al., 2001), it is thus possible that the selective effects of US on TGF- $\beta$ gene expression, which we observed at $1 \mathrm{~h}$, may at least partly explain the response of the OP and ALP genes to US at early time periods.

The present study has additionally examined the physical acoustic mechanisms by which US may exert a biological effect on target cells, at least in vitro, and thus the likelihood of similar cell responses occurring in vivo. Heating, cavitation and acoustic streaming are the main in vitro physical acoustic mechanisms (Dyson, 1987). Because a 2-fold increase in gene expression was observed for both TGF- $\beta 1$ and TGF- $\beta 3$ expression at $130 \mathrm{~mW} / \mathrm{cm}^{2}$, any single physical effect determining such cell responses should therefore be apparent at this lowest dose. However, heating effects, generated from the absorption of acoustic energy and capable of modulating cellular metabolism (Dyson, 1987), caused only a maximum rise of $0.1^{\circ} \mathrm{C}$ at the lowest intensity, which is well within the routine variation of a cell culture incubator and thus not likely to have induced the gene responses observed. Cavitation 
effects, which result from the formation and activity of gas bodies within an US field which can induce localized fluid streaming and cell damage (Dyson, 1987), were evident at the highest dose of US, but not detected at lower intensities and are thus also unlikely to explain the TGF- $\beta$ gene effects of US. However, acoustic streaming, which can induce fluid shear stress along the cell membrane, altering membrane permeability and in extreme cases causing lysis (Dyson, 1987), was noted at all doses, with velocity values similar to those reported for $3.5 \mathrm{MHz}$ transducers under comparable conditions (Duck, 2002). Previous fluid flow experiments showed that similar flow velocities to those measured in this work induce prostaglandin $\mathrm{E} 2$ ( $\mathrm{PGE}_{2}$ ) and nitric oxide $\mathrm{NO}$ expression by osteoblasts (Smalt et al., 1997), with pulsatile flow patterns also altering ALP expression (Hillsley and Frangos, 1997) and modulating cellular $\mathrm{Ca}^{2+}$ levels (Hung et al., 1996). Moreover, the rapid up-regulation of the TGF- $\beta 1$ gene expression, as found in this study, has been reported from fluid flow-induced shear stresses of bone cells in vitro (Sakai et al., 1998). These observations thus suggest that US-induced fluid shear, rather than heating and cavitational events, is likely to be a main physical acoustic mechanism by which US elicits the changes in TGF- $\beta$ gene expression in vitro. It is notable that fluid streaming induced in bone canaliculi by bone strain has also been reported to mediate bone cell function in vivo (Weinbaum et al., 2001).

\section{Acknowledgements}

This work was supported by a grant from the Oxfordshire Health Services Research Committee.

\section{References}

Azuma Y, Ito M, Harada Y, Takagi H, Ohta T, Jingushi S (2001) Low-intensity pulsed ultrasound accelerates rat femoral fracture healing by acting on the various cellular reactions in the fracture callus. J Bone Miner Res 16: 671-680.

Bonewald LF (1999) Regulation and regulatory activities of transforming growth factor beta. Crit Rev Eukaryot Gene Expr 9: 33-44.

Chao EYS, Inoue N (2003) Biophysical stimulation of bone fracture repair, regeneration and remodeling. Eur Cell Mater 6: 72-85.

Cho TJ, Gerstenfeld LC, Einhorn TA (2002) Differential temporal expression of members of the transforming growth factor beta superfamily during murine fracture healing. J Bone Miner Res 17: 513-520.

Clover J, Gowen M (1994) Are MG63 and HOS TE85 human osteosarcoma cell lines representative models of the osteoblastic phenotype? Bone 15: 585-591.

Croucher PI, Russell RGG (1999) Growth Factors in: Seibel MJ, Robins SP, Bilezikian JP (Eds.) Dynamics of bone and cartilage metabolism. Academic Press, San Diego. pp. 453-464.
Das SJ, Olsen I (2001) Up-regulation of keratinocyte growth factor and receptor: a possible mechanism of action of phenytoin in wound healing. Biochem Biophys Res Commun 282: 875-881.

Duck FA (2002) Nonlinear acoustics in diagnostic ultrasound. Ultrasound Med Biol 28: 1-18.

Dyson M (1987) Mechanisms involved in therapeutic ultrasound. Physiotherapy 73: 116-120.

El-Sherif AM, Seth R, Tighe PJ, Jenkins D (2000) Decreased synthesis and expression of TGF-beta1, beta2, and beta3 in epithelium of HPV 16-positive cervical precancer: a study by microdissection, quantitative RTPCR, and immunocytochemistry. J Pathol 192: 494-501.

Fagenholz PJ, Warren SM, Greenwald JA, Bouletreau PJ, Spector JA, Crisera FE, Longaker MT (2001) Osteoblast gene expression is differentially regulated by TGF-beta isoforms. J Craniofac Surg 12: 183-190.

Harle J, Salih V, Mayia F, Knowles JC, Olsen I (2001a) Flow cytometry analysis of the effects of ultrasound on bone and periodontal cells. Ultrasound Med Biol 27: 579586.

Harle J, Salih V, Knowles JC, Mayia F, Olsen I (2001b) Effects of therapeutic ultrasound on osteoblast gene expression. J Mater Sci Mater Med 12: 1001-1004.

Heckman JD, Ryaby JP, McCabe J, Frey JJ, Kilcoyne RF (1994) Acceleration of tibial fracture healing by noninvasive, low intensity pulsed ultrasound. J Bone Joint Surg Am 74: 26-34.

Hillsley MV, Frangos JA (1997) Alkaline phosphatase in osteoblasts is down-regulated by pulsatile fluid flow. Calcif Tissue Int 60: 48-53.

Hung CT, Allen FD, Pollack SR, Brighton CT (1996) Intracellular $\mathrm{Ca}^{2+}$ stores and extracellular $\mathrm{Ca}^{2+}$ are required in the real-time $\mathrm{Ca}^{2+}$ response of bone cells experiencing fluid flow. J Biomech 29: 1411-1417.

Kristiansen TK, Ryaby JP, McCabe J, Frey JJ, Roe LR (1997) Accelerated healing of distal radius fractures with the use of specific, low-intensity ultrasound: A multicenter, prospective, randomized, double - blind, placebo controlled study. J Bone Joint Surg Am 79: 961-973.

Lin FH, Lin CC, Lu CM, Liu HC, Wang CY (1995) The effects of ultrasonic stimulation on DP-bioglass bone substitute. Med Eng Phys 17:20-26.

Morton KI, ter-Haar GR, Stratford IJ, Hill CR (1982) The role of cavitation in the interaction of ultrasound with V79 Chinese hamster cells in vitro. Br J Cancer 45: S147S150.

Naruse K, Mikuni-Takagaki Y, Azuma Y, Ito M, Ota T, Kameyama K, Itoman M (2000) Anabolic response of mouse bone-marrow-derived stromal cell clone ST2 cells to low-intensity pulsed ultrasound. Biochem Biophys Res Commun 268: 216-220.

Neppiras EA (1968) Measurement of acoustic cavitation. IEEE Trans Sonics Ultrasonics 2: 81-88.

Noda M, Camilliere JJ (1989) In vivo stimulation of bone formation by transforming growth factor-beta Endocrinology 124: 2991-2994.

Pilla AA, Mont MA, Nasser PR, Khan SA, Figueiredo M, Kaufman JJ, Siffert RS (1990) Non-invasive lowintensity pulsed ultrasound accelerates bone healing in the rabbit. J Orthop Trauma 4: 246-253. 
Reher P, Elbeshir EI, Harvey W, Meghji S, Harris M (1997) The stimulation of bone formation in vitro by therapeutic ultrasound. Ultrasound Med Biol 23: 12511258.

Rosier RN, O’Keefe RJ, Hicks DG (1998) The potential role of transforming growth factor beta in fracture healing. Clin Orthop 355: S294-S300.

Rubin CT, Lanyon LE (1984) Regulation of bone formation by applied dynamic loads. J Bone Joint Surg Am 63: 397-402.

Ryaby JT, Mathew J, Duarte-Alves P (1992) Low intensity pulsed ultrasound affects adenylate cyclase and TGF- $\beta$ synthesis in osteoblastic cells. Trans Orthop Res Soc 17: 590.

Sakai K, Mohtai M, Iwamoto Y (1998) Fluid shear stress increases transforming growth factor beta 1 expression in human osteoblast-like cells: modulation by cation channel blockades. Calcif Tissue Int 63: 515-520.

Smalt R, Mitchell FT, Howard RL, Chambers TJ (1997) Induction of $\mathrm{NO}$ and prostaglandin $\mathrm{E} 2$ in osteoblasts by wall-shear stress but not mechanical strain. Am J Physiol 273: E751-E758.

Steinbrech DS, Mehrara BJ, Rowe NM, Dudziak ME, Luchs JS, Saadeh PB, Gittes GK, Longaker MT (2000) Gene expression of TGF-beta, TGF-beta receptor, and extracellular matrix proteins during membranous bone healing in rats. Plast Reconstr Surg 105: 2028-2038.

Tanzer M, Kantor S, Bobyn JD (2001) Enhancement of bone growth into porous intramedullary implants using non-invasive low intensity ultrasound J Orthop Res 19: 195-199.

Tanzer M, Harvey E, Kay A, Morton P, Bobyn JD (1996) Effect of noninvasive low intensity ultrasound on bone growth into porous-coated implants. J Orthop Res 14: 901-906.

Wang SJ, Lewallen DG, Bolander ME, Chao EY, Ilstrup DM, Greenleaf JF (1994) Low intensity ultrasound treatment increases strength in a rat femoral fracture model. J Orthop Res 12: 40-47.

Warden S, McMeeken J (2002) Ultrasound usage and dosage in sports physiotherapy. Ultrasound Med Biol 28: 1075-1080.

Warden SJ, Favaloro JM, Bennell KL, McMeeken JM, Ng KW, Zajac JD, Wark JD (2000) Low-intensity pulsed ultrasound stimulates a bone-forming response in UMR106 cells. Biochem Biophys Res Commun 286: 443-450.

Weinbaum S, Guo P, You L (2001) A new view of mechanotransduction and strain amplification in cells with microvilli and cell processes. Biorheology 38: 119-142.

Wolff J (1986) The law of bone remodeling. Springer, Berlin.

Yang RS, Lin WL, Chen YZ, Tang CH, Huang TH, Lu BY, Fu WM (2005) regulation by ultrasound treatment on the integrin expression and differentiation of osteoblasts. Bone 36: 276-283.

Zauhar G, Starritt HC, Duck FA (1998) Studies of acoustic streaming in biological fluids with an ultrasound doppler technique. Br J Radiol 71: 297-302.
Zhuang H, Wang W, Tahernia AD, Levitz CL, Luchetti WT, Brighton CT (1996) Mechanical strain-induced proliferation of osteoblastic cells parallels increased TGFbeta 1 mRNA. Biochem Biophys Res Commun 229: 449453.

\section{Discussion with Reviewers}

D. Jones: In the introduction the authors mention a lot of ways that bone might be stimulated by physical interactions, implying that they are all in someway related at the biophysical level. Can you amplify on the justification for this? Given that cells, if they do react to a stimulus only have a limited choice of responses.

Authors: The mass, architecture and mineral content of bone is known to be governed, to some extent, by adaptive mechanisms that are sensitive to the local mechanical environment, as first described by Wolff's law. The beneficial effects of ultrasound in fracture healing may result from the same underlying mechanosensory response, as indeed many effects from other physical stimuli.

Up to twenty percent of bone volume is made up of proteoglycan-rich ionic fluid (Gong et al., 1964) which is known to flow through the pores and channels of bone extracellular matrix under compressive forces from bending or motion. The electrokinetic effects of such ionic fluid flow induce Stress Generated Potentials (SGPs) across bone that can be measured in vivo during cyclical bending experiments, with SGP magnitude closely related to the subsequent rate of new bone formation (Turner et al., 1994) .

The ultrasonic streaming mechanism, as highlighted in this work, may also drive fluid flow through channels, such as the 0.1-1.0 $\mu \mathrm{m}$ diameter canaliculi in bone. This will induce fluid shear along canaliculi walls and across the cell membranes or cell processes of bone cells, such as osteocytes, which are in contact with canaliculi. A growing literature exists describing the effects of fluid shear on bone cells in vitro, with many reports describing the subsequent up-regulation of a range of growth factor and local signaling molecules, which may play important roles in mediating or initiating the fracture healing process.

The ionic nature of the fluid volume within bone may also explain findings that other physical agents enhance fracture healing in vivo, such as time-varying electromagnetic fields. These physical stimuli may be capable of inducing forces on the fluid in vivo, with resultant fluid streaming and shear in canaliculi due to the fluid's electrically-charged ionic nature.

\section{Additional References}

Gong JK, Arnold JS, Cohn SH (1964) Composition of trabecular and cortical bone. Anat Rec 149: 325-331.

Turner CH, Forwood MR, Otter MW (1994) Mechanotransduction in bone: do bone cells act as sensors of fluid flow? FASEB J 8:875-878. 